\begin{tabular}{|c|c|}
\hline Title & Detection of UVBR-sensitive and -tolerant bacteria in surface waters of the western North Pacific \\
\hline Author(s) & Kataoka, Takafumi; Hodoki, Y oshikuni; Suzuki, Koji; Saito, Hiroaki; Higashi, Seigo \\
\hline Citation & $\begin{array}{l}\text { Journal of Photochemistry and Photobiology B : Biology, 95(2), } 108-116 \\
\text { https://doi.org/10.1016/.jphotobiol.2009.02.004 }\end{array}$ \\
\hline Issue Date & 2009-05-04 \\
\hline DOC URL & http:/hdl.handle.net/2115/40061 \\
\hline Type & article (author version) \\
\hline File Information & JPPB95-2_108-116.pdf \\
\hline
\end{tabular}

Instructions for use 


\title{
Detection of UVBR-sensitive and -tolerant bacteria in surface waters of the western North Pacific
}

\author{
Takafumi Kataoka ${ }^{1, *}$, Yoshikuni Hodoki ${ }^{2,4}$, Koji Suzuki ${ }^{1,2}$, \\ Hiroaki Saito $^{3}$, Seigo Higashi ${ }^{1,2}$ \\ ${ }^{1}$ Graduate School of Environmental Science, Hokkaido University, \\ Kita-ku, Sapporo 060-0810, Japan \\ ${ }^{2}$ Faculty of Environmental Earth Science, Hokkaido University, \\ Kita-ku, Sapporo 060-0810, Japan \\ ${ }^{3}$ Tohoku National Fisheries Research Institute, Fisheries Research Agency, \\ Shinhama-cho 3-27-5, Shiogama 985-001, Japan \\ ${ }^{4}$ Present address: Research Center for Coastal Lagoon Environments, Shimane \\ University, Nisikawatu-cho 1060 Matsue 690-8504, Japan \\ *Email: tak-g-k@ees.hokudai.ac.jp
}


Abstract: In order to evaluate the effects of solar ultraviolet radiation (UVR) on eubacterial community composition, we examined the tolerance of eubacterial phylotypes to solar UV radiation in surface waters of the western North Pacific during September 2005. Bromodeoxyuridine (BrdU), a halogenated thymine analogue, was used for labeling newly synthesized DNA in proliferating cells. Thymine dimers (TD), which are specifically formed in DNA by biologically harmful ultraviolet B radiation (UVBR; 280-315 nm), were also applied to detect UVB damaged genomes selectively. PCR-denaturing gradient gel electrophoresis (PCR-DGGE) on the labeled samples revealed that UVBR-resistant cells showing active synthesis of DNA without accumulating TD, varied among phylotypes. In addition, UVBR-sensitive band positions with TD indicated inter-specific variations in sensitivity to UVBR. Phylogenetic analysis revealed that 12 DNA sequences were classified into 8 phylogenetic groups: 3 Roseobacter, 1 Sphingomonas, 2 Gammaproteobacteria, 1 Actinobacteria, 1 Synechococcus, 2 Prochlorococcus, 1 plastid and 1 another group. A UVBR-resistant phylotype was affiliated to Erythrobacter sp. (previously designated as Sphingomonas sp.), which was distributed in warmer waters from the south of Oyashio to Kuroshio regions. A UVBR-sensitive phylotype was affiliated to Pseudoalteromonas sp. in Gammaproteobacteria. Dominant heterotrophic eubacteria were composed of both sensitive and resistant phylotypes. This is the first report on TD accumulated eubacterial phylotypes in oceanic surface waters.

KEY WORDS: UVBR · Thymine dimer $\cdot$ Phylotype $\cdot$ DGGE $\cdot$ Immunocapture $\cdot$ Marine bacteria 


\section{Introduction}

Recent studies have shown that solar UVB radiation (UVBR: 280 to $315 \mathrm{~nm}$ ) could negatively influence many aquatic organisms. Exposure to solar UV radiation (UVR) can reduce biological productivity, affect reproduction, and increase mutation rate in microorganisms, macroalgae, eggs, larval stage of fish, and other aquatic animals [1]. Aquatic bacteria, which are a major component of aquatic ecosystems and play a key role in biogeochemical processes such as nutrient cycling [2], are also sensitive to solar UVR, especially biologically harmful UVBR because of their lack of pigments, small cell size and short generation time $[3,4]$.

Although DNA shows peak absorbance at around $260 \mathrm{~nm}$, the absorption spectrum of DNA covers the wavelength of UVBR. As a result, UVBR induces DNA damage and causes dimerizations between adjacent pyrimidine bases (i.e. so-called thymine dimers; $[5,6])$. The photoproducts interfere with DNA replication and transcription by RNA, since DNA polymerase and reverse transcriptase are stalled or physically blocked by the structural changes in the DNA molecules. In field studies, DNA damage in marine bacteria was greater in those found in surface waters than those in deeper waters [7-9]. Furthermore, higher amounts of DNA photoproducts were found during daytime than at night, indicating that the accumulation of DNA damage occurred under daylight, and its removal took place under dark conditions. UVBR inhibited about $45 \%$ of tritiated thymidine (TdR) incorporation, which is widely used as a marker for DNA synthesis by labeling the DNA inside proliferating cells $[10,11]$ in bacterial communities $[3,12]$.

Although the effects of UVR, especially UVBR, on bulk bacterial communities have been studied in the past two decades, little information is available about the impact of UVR on bacterial community composition. Some previous studies used bacterial isolates originating from seawater, and showed interspecific variability not only in the accumulation of thymine dimers [13], but also in the subsequent repair of DNA 
damages [14,15]. However, such isolates may be only minor components of natural bacterial populations [16]; because most bacteria are not cultivable in the laboratory, it is still uncertain whether the results of these studies represent the natural bacterial community.

Recent developments in molecular techniques have contributed to revealing the existence of uncultivable bacterial phylotypes. Culture-independent finger printing techniques such as PCR-denaturing gradient gel electrophoresis (DGGE) are useful tools for detecting major phylotypes in the natural bacterial community $[17,18]$. Such molecular techniques have been applied to the studies of UVR effects in aquatic organisms. For instance, using PCR-DGGE analysis based on 16S rDNA, Winter et al. [19] found a few UVR sensitive phylotypes in UVR-transparent mesocosms. They also found differential phylotypes in active bacterial communities using PCR-DGGE analysis based on double-stranded cDNA synthesized from mRNA of 16S rRNA gene. Recently, using microautoradiography combined with a catalyzed reporter deposition-fluorescence in situ hybridization (MAR-CARD-FISH) technique, Alonso-Sáez et al. [20] found that UVR effects on bacterial activity differed among the group levels in the coastal region of the NW Mediterranean sea. An immunological technique for detecting DNA damage of marine microorganisms has been developed by Buma et al. [21] and has been widely used to quantify thymine dimers [22]. Immunocapturing techniques have also been developed for the detection and enrichment of selected bacteria [23]. By using an immunocapturing technique in which magnetic beads conjugated with a secondary antibody, it is possible to separate DNA photoproducts from normal DNA fractions [6]. However, this technique has never been applied to natural bacterial communities. Similarly, an immunocapturing technique using bromodeoxyuridine (BrdU) and anti-BrdU antibody conjugated with magnetic beads allows the separation of DNA fragments of actively growing bacteria from the total DNA $[24,25]$. This technique has recently been used for quantification 
of DNA-synthesizing bacteria in seawater [26-31]. PCR-DGGE combined with the immunocapturing method succeeded in distinguishing actively growing bacteria from the bacterial community in the ocean [32-34].

In this study, we applied PCR-DGGE combined with immunocapturing techniques to detect actively growing and UV-damaged eubacteria in the northwest Pacific using anti-BrdU and anti-thymine-dimers, respectively. At the same time, the total eubacterial community composition was also assessed by PCR-DGGE targeted to 16S rRNA gene. This is the first report on UVBR-sensitive or -resistant eubacterial phylotypes in the oceanic environment.

\section{Materials and Methods}

\subsection{Sampling and hydrography}

Water samples were collected along the "A-line" during September 14-18 in 2005 on board the FR/V Wakataka Maru (Fisheries Research Agency of Japan). Seawater samples were collected from $0 \mathrm{~m}$ depth with an acid-cleaned plastic bucket. The water samples were divided into acid-cleaned polycarbonate bottles. To detect total (non-immunocapturing) eubacterial populations and thymine dimers, subsamples $(1 \mathrm{~L})$ were filtered through $0.2 \mu \mathrm{m}$ pore size polycarbonate Nuclepore filters (Whatman) with gentle vacuum pressure $(<150 \mathrm{mmHg})$ under dim light within 60 minutes of sampling under dim light. The filters were immediately frozen in liquid nitrogen and stored at $-80^{\circ} \mathrm{C}$ until analysis. The other subsamples were used for the enumeration of heterotrophic bacteria and BrdU-labeling on-deck incubation experiments (see below). Hydrographic data (seawater temperature, salinity, and nutrient concentrations) were obtained from the cruise database. Stations were grouped into three water masses: the Oyashio: $<5^{\circ} \mathrm{C}$ and $<33.6$ in salinity at $100 \mathrm{~m}$ depth [35], the Kuroshio: $>14^{\circ} \mathrm{C}$ at $200 \mathrm{~m}$ depth [36], and the other stations were treated as the Kuroshio-Oyashio transition 
region.

\subsection{Measurement of solar radiation}

During the sampling period, solar UVB $(280-315 \mathrm{~nm})$ radiation was measured with a broadband UVB radiometer (MS-212W, Eko instruments, Co. Ltd.) and UVA (315-400 nm) with a broadband UVA radiometer (MS-212A, Eko instruments, Co. Ltd.). Photosynthetically active radiation (PAR; 400-700 nm) was also measured with a photon sensor (ML-020, Eko instruments, Co. Ltd.). All sensors were attached to the compass deck, and were open to the air.

\subsection{Cell density of heterotrophic bacteria}

Subsamples $(2 \mathrm{ml})$ were fixed with glutaraldehyde $(2 \%(\mathrm{w} / \mathrm{v})$ final concentration), stored at $4^{\circ} \mathrm{C}$, and analyzed on land after 30 days from the each sampling. All of the analyses were conducted under dim light conditions. The fixed samples $(1-1.5 \mathrm{ml})$ were mixed with SYBR Gold (Molecular Probes Inc.) at a 1/10,000 dilution rate for 15 min to stain the DNA in the bacterial cells. Stained subsamples were filtered through black polycarbonate Nuclepore filters $(25 \mathrm{~mm}$ in diameter, $0.2 \mu \mathrm{m}$ in pore size, Whatman) with gentle vacuum pressure $(<150 \mathrm{mmHg})$. Each filter was washed twice with $2 \mathrm{ml}$ of $0.2-\mu \mathrm{m}$-filtered seawater and then dried in a desiccator thereafter. The filter was placed onto a glass slide, one drop of non-fluorescing immersion oil (Olympus Co.) was dropped onto the glass, and then the filter was covered with a coverslip. Bacterial cells were counted at a magnification of $\times 1,000$ on an Olympus epifluorescence microscope (model BX 60) equipped with a $100 \mathrm{~W}$ mercury lamp. The excitation, dichroic, and emission wavelengths were 360-370 nm (BP360-370), $400 \mathrm{~nm}$ (DM400), and 420-460 nm (BA420-460), respectively. Bacterial cells with green fluorescence of SYBR Gold intercalated into DNA were counted, where there were at least 200 cells in a scope field. Twenty scope fields, selected randomly, were 
examined in this study.

\subsection{BrdU labeling}

Bromodeoxyuridine (BrdU) was added to triplicates of subsamples $(50 \mathrm{ml})$ at a final concentration of $20 \mu \mathrm{M}$ as soon as possible after sampling, and samples were incubated in the dark for $60 \mathrm{~min}$ at in situ temperature. After incubation, the seawater samples were filtered through polycarbonate Nuclepore membrane filters $(0.2 \mu \mathrm{m}$ pore size, Whatman). The filters were immediately frozen in liquid nitrogen and stored in a deep freezer $\left(-80^{\circ} \mathrm{C}\right)$ until analysis on land.

\subsection{DNA extraction}

DNA extraction was performed after Katano et al. [37] as follows. The filters were ground in a lysis solution ( $30 \mu 110 \% \mathrm{v} / \mathrm{v}$ sodium dodecyl sulfate, $500 \mu \mathrm{l}$ Tris-EDTA (TE) buffer, and $3 \mu 110 \mathrm{mg} \mathrm{ml}^{-1}$ proteinase $\mathrm{K}$ ) with autoclaved plastic pestles and incubated at $37^{\circ} \mathrm{C}$ for $1 \mathrm{~h}$. Cell lysates were frozen and thawed three times. To remove polysaccharides, a mixture of cetyltrimethlammonium bromide (CTAB, Wako) and $0.7 \mathrm{M} \mathrm{NaCl}$ solution was added, and the solution was incubated at $65^{\circ} \mathrm{C}$ for 10 min. Polysaccharides and proteins were removed with chloroform-isoamyl alcohol (24:1) and then eliminated with phenol-chloroform-isoamyl alcohol (25:24:1). DNA precipitated with ice-cold isopropanol was rinsed with ice-cold $70 \%$ ethanol and resuspended in $100 \mu \mathrm{TE}$ buffer. Then the DNA in solution was precipitated with ice-cold $100 \%$ ethanol, rinsed with ice-cold $70 \%$ ethanol, and resuspended in $47 \mu \mathrm{TE}$ buffer. The molecular weight of DNA in each extract was determined by electrophoresis of $5 \mu 1$ of extract on a $1.5 \%$ agarose gel with a 100 bp DNA ladder (New England Biolabs, Inc.). The concentration of DNA in the extracts was quantified by a spectrophotometer (GeneQuant ${ }^{\mathrm{TM}}$, GE Healthcare) and adjusted to $1 \mathrm{ng} \mu \mathrm{l}^{-1}$ in TE 
buffer.

\subsection{Immunocapturing using anti-BrdU antibody}

Immunoglobulin-coated paramagnetic beads were used to selectively isolate BrdU-containing DNA from labeled environmental samples. BrdU magnetic bead immunocapture was performed after Urbach et al. [25]. Herring sperm DNA (1.25 mg $\mathrm{ml}^{-1}$ in PBS), which had been denatured at $95^{\circ} \mathrm{C}$ for $5 \mathrm{~min}$ and quickly frozen at $-20^{\circ} \mathrm{C}$ was mixed at 49:1 ratio with monoclonal anti-BrdU antibody (diluted 1:49 in PBS), and incubated for $30 \mathrm{~min}$. DNA samples denatured at $95^{\circ} \mathrm{C}$ for $5 \mathrm{~min}$, and frozen on ice were mixed with herring sperm DNA and anti-BrdU antibody mixture (hereafter referred to as complex-1) at $37^{\circ} \mathrm{C}$ for $45 \mathrm{~min}$ to immunologically conjugate the $\mathrm{BrdU}$ incorporated in DNA of bacterial cells with anti-BrdU antibody. A sheep anti-Mouse IgG secondary antibody coated with paramagnetic beads (Dynal Biotech) was pre-washed five times in PBS containing $1 \mathrm{mg}$ of bovine serum albumin (Sigma) per $\mathrm{ml}$ (PBS-BSA), gathered with a magnetic particle concentrator (Dynal Biotech), and resuspended in PBS-BSA with the an initial concentration of $6-7 \times 10^{8}$ beads $\mathrm{ml}^{-1}$. A $3.13 \mu 1$ aliquot of antibody with beads was added to each sample and subsequently incubated at $37^{\circ} \mathrm{C}$ for $30 \mathrm{~min}$ with constant agitation to form complex-1-beads complex (complex-2), then complex-2 was washed seven times with $100 \mu 1$ of PBS-BSA each time. A fraction of sample DNA containing BrdU was eluted into supernatants by adding $1.7 \mathrm{mM}$ BrdU (in PBS-BSA) and incubated at $37^{\circ} \mathrm{C}$ for $30 \mathrm{~min}$ with constant agitation. The supernatant was collected in a new tube, and $2 \mu 1$ of glycogen $(20 \mathrm{mg}$

$\mathrm{ml}^{-1}$, Wako) was added to the sample for DNA precipitation. Each immunocaptured DNA sample was finally resuspended in $20 \mu \mathrm{l}$ of TE buffer.

\subsection{Immunocapturing using anti-thymine dimer antibody}

TD-containing DNA was also selectively isolated from environmental 
samples using immunoglobulin-coated paramagnetic beads through the partially modified protocol of BrdU-immunocapturing. Briefly, denatured herring sperm DNA (1.25 mg ml $\mathrm{mg}^{-1}$ in PBS) was mixed at 49:1 ratio with monoclonal anti-TD antibody (BM12, Kyowa), and incubated for $30 \mathrm{~min}$. Denatured DNA samples were mixed with herring sperm DNA and anti-TD antibody mixture (complex-1) at $37^{\circ} \mathrm{C}$ for $45 \mathrm{~min}$ to combine the anti-TD and TD included in sample DNA. An aliquot of washed sheep anti-Mouse IgG-coated paramagnetic beads (Dynal Biotech) was added to each sample and subsequently incubated. TD containing the sample DNA fraction was eluted into supernatants by heat shock at $95^{\circ} \mathrm{C}$ for 5 min and quickly frozen on ice, then collected in a new tube for isopropanol precipitation. Immunocaptured sample DNA was finally resuspended into $20 \mu 1$ of TE buffer.

\subsection{PCR for $D G G E$}

We PCR-amplified $550 \mathrm{bp}$ of the eubacterial 16S rRNA gene using a universal primer complementary to positions 907-926 (Escherichia coli numbering; (5'-CCGTCAATTCMTTTGAGTTT-3') and complementary to positions 341-357 plus a GC clamp (5'-CGCCCGCCGCGCCCCGCGCCCGTCCCGCCGCCCCCGCCCG-CCTA CGGGAGGCAGCAG-3'; [17,38]). PCR mixtures were prepared in $20 \mu$ l total volume containing $1 \times \mathrm{Ex} \mathrm{Taq}^{\mathrm{TM}}$ Buffer (TaKaRa), $2.2 \mathrm{mM} \mathrm{MgCl}_{2}, 0.5 \mathrm{mM}$ dNTP, $0.25 \mu \mathrm{M}$ of each primer, 2.5 units of Taq DNA polymerase (Ex Taq ${ }^{\mathrm{TM}}$; TaKaRa) and approximately 2 pg of template DNA. PCR conditions followed those of Muyzer et al. [17] with the exception of initial denaturation at $95^{\circ} \mathrm{C}$ for $5 \mathrm{~min}$. PCR amplification consisting of 35 cycles was performed using a thermal cycler (Eppendorf Mastercycler Personal). PCR products $(2 \mu \mathrm{l})$ were loaded on a $1.5 \%$ agarose gel and electrophoresed with a $100 \mathrm{bp}$ DNA ladder marker (New England Biolabs, Inc.). The agarose gel was stained with ethidium bromide (Et-Br) and photographed as a digital file. Then 5-8 targeted amplicons were mixed in order to avoid PCR bias, and the mixture was concentrated by 
ethanol precipitation. The amount of DNA was estimated from its relative intensity compared with the DNA ladder marker on the agarose gel electrophoresis. Band density was determined using Gel-pro Analyzer ${ }^{\circledR}$ version 4.5 (Media Cybernetics).

PCR products (ca. $100 \mathrm{ng}$ of DNA) were loaded onto a $16 \times 16 \mathrm{~cm}, 1 \mathrm{~mm}$ thick, $6 \%$ polyacrylamide (acrylamide:bis $=37.5: 1)$ gel with a denaturing gradient of $25-70 \%$ from top to bottom (7 M urea and 40\% formamide were considered as $100 \%$ denaturant). Electrophoresis was performed with a Dcode system (Bio-Rad Laboratories) using $1 \times$ TAE running buffer (20 mM Tris, $10 \mathrm{mM}$ acetic acid, $0.5 \mathrm{mM}$ EDTA, $\mathrm{pH} 8.0$ ) at $60^{\circ} \mathrm{C}$ for $16 \mathrm{~h}$ at $85 \mathrm{~V}$. The gel was stained for $30 \mathrm{~min}$ in 1:10,000 diluted SYBR Gold (Molecular Probes, Inc.) and destained for $20 \mathrm{~min}$ in distilled water. The DGGE gel was visualized using an Invitrogen Safe Imager and photographed using a Canon digital camera with a high resolution mode.

\subsection{Analysis of DGGE patterns}

DGGE images were analyzed with a one-dimensional gel analysis tool in the Gel-Pro Analyzer ${ }^{\circledR}$ software (ver. 4.5, Media Cybernetics, Inc). To detect DGGE bands, a density profile was obtained for estimating the ratio of each band's intensity to the total intensity. Bands with relative intensity of $\geq 0.4 \%$ were considered significant in this study. A binary matrix was constructed, taking into account the presence (1) or absence (0) of bands in each lane [39]. The dissimilarity in band-pattern between pairs of samples on the same gel was calculated as a Dice coefficient $\left(S_{\text {Dice }}\right)$ :

$$
S_{\text {Dice }}=2 N_{\mathrm{AB}} /\left(N_{\mathrm{A}}+N_{\mathrm{B}}\right)
$$

where $\mathrm{N}_{\mathrm{AB}}$ is the number of bands found in both patterns, and $N_{\mathrm{A}}$ and $N_{\mathrm{B}}$ represent the total number of bands in samples A and B, respectively. A distance matrix was analyzed with unweighted pairwise grouping with mathematical averages (UPGMA) to cluster 
samples using an average pairwise algorithm. Statistical calculations were performed with the software R (ver. 2.7.2).

\subsection{Sequencing analysis}

To obtain sequence information from DGGE bands, all visualized bands were excised using a clean razor blade. The cut bands were then washed twice using $2 \mathrm{ml}$ of sterilized Milli-Q water and frozen until re-amplification with PCR. About $1 \mathrm{~mm}^{3}$ of each band was directly re-amplified. PCR was conducted according to Muyzer et al. [17], with modifications: except initial template denaturing at $95^{\circ} \mathrm{C}$ for $5 \mathrm{~min}$, followed by 20 cycles of denaturation $\left(1 \mathrm{~min}\right.$ at $95^{\circ} \mathrm{C}$ ), annealing $\left[1 \mathrm{~min}\right.$ at $65-55^{\circ} \mathrm{C}$ (touchdown $-1^{\circ} \mathrm{C}$ cycle $\left.{ }^{-1}\right)$, and extension $\left(3 \mathrm{~min}\right.$ at $72^{\circ} \mathrm{C}$ ), followed by 7 cycles of denaturing ( $1 \mathrm{~min}$ at $\left.94^{\circ} \mathrm{C}\right)$, annealing $\left(1 \min\right.$ at $\left.55^{\circ} \mathrm{C}\right)$, and extension $\left(3 \min 72^{\circ} \mathrm{C}\right)$, with a final extension $(7$ min at $72^{\circ} \mathrm{C}$ ). After re-amplified bands were examined with DGGE to confirm their band position and non-contamination, PCR products were purified using the polyethylene glycol (PEG) precipitation method. A $15 \mu \mathrm{l}$ subsample of the amplified 16S rDNA solution was diluted with $35 \mu 1$ of distilled water and mixed with $30 \mu 1$ of PEG solution [20\% PEG 6000 (Wako) and 2.5 M NaCl], incubated on ice for $1 \mathrm{~h}$, and centrifuged at $15,000 \mathrm{rpm}$ for $15 \mathrm{~min}$. Precipitates were rinsed with ice-cold $70 \%$ ethanol and resuspended in $20 \mu \mathrm{l}$ of distilled water. The purified amplified products were sequenced on an ABI PRISM ${ }^{\circledR} 3100$ Genetic Analyzer (Applied Biosystems) with both the 907-926 and 341-357 primers without the GC-clamp [17] using a BigDye v1.0 Terminator cycle sequencing kit (Applied Biosystems). Duplicate samples were analyzed to reduce reading errors by the genetic analyzer. Then $16 \mathrm{~S}$ rDNA sequences were analyzed for each sample.

\subsection{Phylogenetic analysis}

Sequences obtained in this study were examined for chimeras, which could be 
generated artificially by co-amplification of homologous genes during PCR reactions, using the Ribosomal Database Project's CHECK-CHIMERA program [40]. Chimeras were also checked with the basic local alignment search tool BLAST [41] for short sequences. Non-chimeric sequences were compared to sequences deposited in the bacterial nucleotide sequence databases (i.e., ddbjbct and ddbjenv) of the DNA Data Bank of Japan (DDBJ). Acquired 16S rRNA gene sequences were assigned to phylogenetic groups based on the most similar sequence found in the DDBJ. Bacterial sequences were aligned using CLUSTAL W, and corrected manually to delete ambiguous and non-informative bases with Mega 3 [42]. A distance tree was constructed using the neighbor-joining (NJ) method based on [43] distance. Bootstrap resampling was performed 10,000 times. The nucleotide sequences of the $16 \mathrm{~S}$ rDNA gene obtained in this study have been deposited in the DDBJ nucleotide sequence database under accession numbers AB449917-AB449930.

\section{Results}

\subsection{Hydrography}

Sampling stations were classified into three regions: Oyashio, Kuroshio-Oyashio transition, and Kuroshio regions (Table 1). Sea surface temperature (SST) increased from north to south along the transect, the lowest was $18.4^{\circ} \mathrm{C}$ at Station A04 and the highest was $25.5^{\circ} \mathrm{C}$ at Station A21. A similar latitudinal gradient pattern was found in chlorophyll $a(\mathrm{Chl} a)$ concentrations (Table 1). Nutrient concentrations were generally low, especially in the southern stations (A13, A17, and A21). The cell density of heterotrophic bacteria ranged from $2.72 \times 10^{5}$ cells ml $^{-1}$ to $6.74 \times 10^{5} \mathrm{cells} \mathrm{ml}^{-1}$, and the lowest value was observed at Station A21 in the Kuroshio region. 


\subsection{UVBR and PAR}

Ambient solar UVR and PAR varied among the stations (Fig. 1, Table 2) mainly due to changes in weather conditions. During observations at Stations A09, A13, and A21, weather conditions were generally favorable and the daily UVBR ranged from $8.75 \mathrm{~kJ} \mathrm{~m}^{-2}$ to $12.89 \mathrm{~kJ} \mathrm{~m}^{-2}$, while those at Stations A04 and A17 were lower (1.99 and $5.28 \mathrm{~kJ} \mathrm{~m}^{-2}$, respectively) because of cloud covers. At four of five stations, Stations A09, A13, A17, and A21, UVBR during the sampling period accounted for $>70 \%$ of each daily value. The ratio of UVBR to UVAR $(0.99 \%)$ at the northernmost Station A04 was lower than that (1.39 to $1.51 \%)$ of the other stations. Similarly, daily PAR ranged from 33 mol photons $\mathrm{m}^{-2}$ to 43 mol photons $\mathrm{m}^{-2}$ at Stations A09, A13, and A21, while those at Stations A04 and A17 were lower (3 and $11 \mathrm{~mol} \mathrm{~m}^{-2}$, respectively).

\subsection{PCR-DGGE}

BrdU-immunocapturing combined with DGGE analysis produced banding patterns of BrdU incorporating the community in the study area (Fig. 2). Similarly, TD-immunocapturing combined with DGGE also showed banding patterns of a TD-accumulating community (Fig. 2). These two bacterial community profiles were compared with total bacterial populations (Fig. 2). The clustering analysis of DGGE profiles distinguished total bacterial community composition at northern stations in the Oyashio region (i.e. cluster A; Station A04) from those at southern Oyashio and Kuroshio-Oyashio transition regions (i.e. cluster B; Stations A09, A13, and A17) (Fig. 3). The Kuroshio bacterial community at Station A21 was distinctively clustered (Fig. 3).

To identify UVB-resistant phylotypes, DGGE bands between total and thymine dimmers (TD)-immunocaptured 16S rDNA fractions were compared with each other. DGGE band positions appeared in BrdU lanes, but not in TD lanes, indicating the phylotypes that were actively growing without accumulating TD (hereafter the 
phylotypes are referred to AT), that is, those that were resistant to UVBR. Similarly, DGGE band positions appeared in TD lanes, but not in BrdU lanes indicating the phylotypes, which were inactive with accumulating TD (hereafter the phylotypes are referred to IT), that is, those that were sensitive to UVBR. The number of DGGE bands indicating UVBR-resistant phylotypes ranged from 0-2 at each station and the maximum was observed at Stations A04 and A13 (Table 3). The number of UVBR-sensitive phylotypes ranged from $2-6$, and the maximum was observed at Station A13.

To estimate the ratios of actively growing or DNA-damaged bacteria to the total number of bacteria, common DGGE bands between total and immunocaptured $16 \mathrm{~S}$ rDNA fragments were counted and then divided by the band numbers total band numbers detected from the 3 lanes. The former ranged from $11-29 \%$ (21\% on average) and the latter was from $21-43 \%$ (34\% on average) (Table 3$)$. The common bands between BrdU and TD lanes were counted as having intermediate tolerance to UVBR (hereafter the phylotypes are referred to as IM). The ratio of IM bands to all band positions including total and immunocaptured bands ranged from 11 to $31 \%$ (21\% on average).

\subsection{Phylogenetic analysis of $16 \mathrm{~S} r R N A$ gene fragments}

We obtained 14 DNA sequences from 45 band positions (Table 4). Six band positions indicated IT bands; band positions 01 at Station A21, 03 at Station A13, 07 at Station A13 and A17, 08 at Stations A04 and A09, 11 at Station A17, and 12 at Stations A21, respectively (Fig. 2). Three band positions represented AT bands; band position 02 at Stations A09 and A13, 09 at Stations A04 and A17, and 10 at Stations A04, respectively (Fig. 2). Four bands (04, 06, 13, and 15 in Fig. 2) were characterized as

IM bands, and band position 13 was common from Station A04 to A21. Two 
phylotypes (NO_1, band position 05; and NO_2, band positions 14) appeared only in a single lane at the stations.

Of the 15 sequences obtained from the study area, 11 sequences had more than 97\% similarity with the closest relatives deposited in the DDBJ and 2 sequences (sequence names AT_3 and IT_6) were less than 97\% in homogeneity. The lengths of the oligonucleotide sequences for IT_4 and $\mathrm{NO}_{-} 2$ were so short that further phylogenetic analysis was, unfortunately, not possible.

In the neighbor-joining (NJ) tree (Fig. 4) using 521 bp sequences using the archaeon Sulfolobus solfataricus as an out-group, 40 sequences were clustered into 8 groups: Roseobacter, Sphingomonas, Gammaproteobacteria, Actinobacteria, Synechococcus, Prochlorococcus, plastids and others. Affiliations of the two unknown phylotypes (AT_3 and IT_6) were revealed by the NJ tree: the sequences of AT_3 and IT_6 were classified into as plastid, and Gammaproteobacteria, respectively.

\section{Discussion}

We identified eubacterial phylotypes with TD in the open ocean. In previous studies carried out in coastal waters, Alonso-Sáez et al. [20] showed that the Gammaproteobacteria and Cytophaga-Flavobacteria-Bacteroides (CFB) groups possessed higher resistance to UVBR in the northwestern Mediterranean, compared to Alphaproteobacteria. In the North Sea, Winter et al. [19], using the PCR-DGGE method based on mRNA fragments of $16 \mathrm{~S}$ rRNA gene, showed that UVBR differentially affected bacterial activity even among phylotypes in CFB group: some phylotypes were sensitive to UVB, while the others were resistant. Our immunocapture-DGGE analysis provided more detailed information about the tolerance of eubacteria to UVBR in phylotype level. In Oyashio and the transition regions, the 
composition of BrdU-incorporating bacterial communities was different from total bacterial communities (Fig. 3). The percentage of overlapping bands for the BrdU-labeled and total bacterial community was $21 \%$ on an average (Table 3). Namely, $80 \%$ of growing bacterial phylotypes were not detected in the total bacterial community. Considering that PCR-DGGE bands indicate the predominant community members [18] and that the BrdU-immunocapture technique can detect actively growing bacteria specifically [25], the difference between the total and the BrdU-immunocaptured bacterial community indicated that more than half of the growing bacterial phylotypes were minor populations. The results obtained in this study are similar to those of Hamasaki et al. [33] who used the same technique. The low abundance of actively growing bacteria could be caused by the differences in phylotype-specific mortality by viral infection, selective ingestion of actively growing bacteria by heterotrophic nanoflagellates $[44,45]$, and/or UVBR $[13,15,46]$.

For UVBR tolerance, $21-43 \%$ (34\% on average) of the bands showed overlapping between the TD and total lanes. This higher percentage supports the previous results that bacteria tended to accumulate DNA damage $[8,13,47]$. Joux et al. [13] showed that five species out of six isolated bacteria easily accumulated thymine dimmers under approximately $1 \mathrm{~kJ} \mathrm{~m}^{-2}$ of UVBR. During sampling, UVB dose were 1.04-10.95 kJ $\mathrm{m}^{-2}$, which reached to $52-87 \%$ of the daily UVBR (Table 2), indicating that the UVBR level was sufficient for the surface bacteria to accumulate TD. It is well known that the amount of TD changes diurnally, that is, TD accumulates from noon to early evening with decreasing $\mathrm{TdR}$ incorporation $[7,8]$. In the Kuroshio-Oyashio transition area of the western North Pacific, more than $35 \%$ of phylotypes of the total bacterial community experienced TD accumulation (Table 3). Repair of TD would become a key strategy for their survival. In addition, the difference in the UVBR tolerance of bacteria (Table 3) could be related to the intensity of UVBR in the environments they inhabited $[46,48]$. 
It should be noted that, in the Oyashio region, the ratio of overlapping bands of the TD-accumulating phylotypes to the total was the smallest at Station A04 (31\%), where UVBR was the lowest and the ratio of UVAR to UVBR was the highest among the stations (Table 2). Since UVAR is important for the photorepair of TD [7,49], low TD accumulation could be due to the high UVAR/UVBR ratio. Another possibility is that low UVBR could lead to low TD accumulation.

Cluster analysis revealed that the total bacterial community composition in the Oyashio region (cluster A) differed from the others (Fig. 3). This was caused by the large number of IM bands that were characterized in the Oyashio region (Table 3). Relatively high concentrations of nutrients and chlorophyll $a$ at Stations A04 and A09 indicate higher photosynthetic activity of phytoplankton and the accumulation of labile dissolved organic matter (DOM) derived from phytoplankton. It is well known that photodegradation of DOM by solar UVR forms low molecular weight DOM [50-54], which is subsequently utilized by heterotrophic bacteria $[55,56]$. In addition, phytoplankton could serve as a sunscreen for bacteria due to absorption and scattering of UVR by the phytoplankton. Thus, the productive Oyashio water might moderate UV stress for bacteria. The two Oyashio-specific phylotypes, Gammaproteobacteria (AT_4) and unknown bacteria (IM_5), might adapt to such conditions.

The phylotypes of the Roseobacter clade were categorized as IT, IM, and NO types (IT_5, IM_2 and, NO_1) and were commonly found among the sampling stations, although the environmental conditions (i.e. concentrations of chlorophyll $a$ and nutrients, and water temperature) were variable (Table 1). Several past studies revealed that Roseobacter clade appeared inconsistently in oceanic waters. For example, González et al. [57] found high abundance of Roseobacter clade during phytoplankton blooms in the North Atlantic. On the other hand, Suzuki et al. [58] could not find any correlation between the distribution of Roseobacter clade and environmental factors (i.e. temperature, nutrients, and chlorophyll $a$ ) in the North 
Pacific off California. Van Mooy et al. [59] showed a significant correlation between the Roseobacter clade numbers and light intensity, while no correlation was found between the bacterial abundance and DOM. The appearance of IM phylotypes at all of our sampling stations also showed the ubiquity of the Roseobacter clade.

A photosynthetic bacteria Erythrobacter sp. (previously called as Sphingomonas sp.) was observed in DGGE bands (AT_1), and was classified as a UVB resistant phylotype. Their preferential distribution from the southern Oyashio to the Kuroshio regions coincided with the warm water tolerance of the genus Erythrobacter citrus, with a growing range of $4-35^{\circ} \mathrm{C}$ and optimum of $25-30^{\circ} \mathrm{C}$ [60]. In addition, Joux et al. [13] showed that the Sphingomonas sp. strain RB2256 formed colonies without accumulating TD even under high UVB $\left(2.0 \mathrm{~kJ} \mathrm{~m}^{-2}\right)$, indicating a high level of UVB resistance, and that the Erythrobacter sp. might repair DNA damage efficiently under solar radiation. Therefore, photosynthetic bacteria with high UVBR tolerance could proliferate in surface waters. As described above, two phylotypes related to Alphaproteobacteria were found. However, TD accumulation was different between the phylotypes, indicating that UV tolerance differs among phylotypes in Alphaproteobacteria, even though their phylogenetic positions based on $16 \mathrm{~S}$ rDNA gene were close to each other.

We also found Gammaproteobacteria (IT_1; Pseudoalteromonas sp.) to be a UVBR-sensitive phylotype that occurred at Station A13 and A17, although it was also present as an intermediate-UVBR-tolerant phylotype at Station A09. At Stations A09 and A13, the environmental conditions such as UVBR, SST, Chl $a$, and nutrient concentrations were very similar (Tables 1 and 2). Although no clear relationship was found between environmental factors and BrdU incorporation or TD accumulation, UVBR sensitivity in bacteria might vary not only with phylotypes but also with environmental and/or physiological conditions. Alonso-Sáez et al. [20] showed variable UVBR sensitivity of Gammaproteobacteria between summer and spring in 
NW Mediterranean coastal waters. Furthermore, UVBR sensitivity of Pseudoalteromonas sp. differed between sampling days, suggesting changes in their physiological conditions on a day-time scale. Recently, inter-specific variation in recovery from UV damage was also investigated using 90 marine bacterial isolates [14], and showed that most of the Gammaproteobacteria had high recovery rates. Simultaneous detections of BrdU incorporation and TD accumulation with physiological parameters such as robustness of ectoenzymes [47] could give more information about bacterial UV tolerance.

In the present study, we showed that about $35 \%$ of phylotypes of the total bacterial community accumulated DNA damage while $20 \%$ were actively growing. The results indicated that proliferating bacteria were also stressed by UVBR. Stratospheric ozone depletion, which increases the ratio of UVBR to UVAR and UVBR to PAR, may shift essential metabolic energy to repair DNA damage for survival. As observed in the present study, the tolerance to UVBR was different among phylotypes. Such information is essential for the prediction of changes in ecosystems and biogeochemical cycles in the ocean.

\section{Acknowledgments}

We would like to thank T. Isada, who helped to collect samples during the cruise and gave us useful comments on nutrients and phytoplankton activity. Grateful thanks are also due to the captains and crews of FR/V Wakataka Maru for their helpful support during cruises. 


\section{References}

[1] D. P. Häder, H. D. Kumar, R. C. Smith, R. C. Worrest, Effects of solar UV radiation on aquatic ecosystems and interactions with climate change, Photoch. Photobil. Sci. 6 (2007) 267-285.

[2] J. B. Cotner, B. A. Biddanda, Small players, large role: Microbial influence on biogeochemical processes in pelagic aquatic ecosystems, Ecosystems 5 (2002) 105-121.

[3] G. J. Herndl, G. Müller-Niklas, J. Frick, Major role of ultraviolet-B in controlling bacterioplankton growth in the surface-layer of the ocean, Nature 361 (1993) 717-719.

[4] R. Sommaruga, I. Obernosterer, G. J. Herndl, R. Psenner, Inhibitory effect of solar radiation on thymidine and leucine incorporation by freshwater and marine bacterioplankton, Appl. Environ. Microbiol. 63 (1997) 4178-4184.

[5] W. H. Jeffrey, P. Aas, M. M. Lyons, R. B. Coffin, R. J. Pledger, D. L. Mitchell, Ambient solar radiation-induced photodamage in marine bacterioplankton, Photochem. Photobiol. 63 (1996) 419-427.

[6] W. H. Jeffrey, J. P. Kase, S. W. Wilhelm, UV radiation effects on heterotrophic bacterioplankton and viuses in marine ecosystems. in: S. de Mora, S. Demers, M. Vernet (Ed.), The effects of UV radiation in the marine environment, Cambridge University press, Cambridge, (2000), pp. 206-236.

[7] P. Boelen, M. J. W. Veldhuis, A. G. J. Buma, Accumulation and removal of UVBR-induced DNA damage in marine tropical plankton subjected to mixed and simulated non-mixed conditions, Aquat. Microb. Ecol. 24 (2001) 265-274.

[8] W. H. Jeffrey, R. J. Pledger, P. Aas, S. Hager, R. B. Coffin, R. VonHaven, D. L. Mitchell, Diel and depth profiles of DNA photodamage in bacterioplankton exposed to ambient solar ultraviolet radiation, Mar. Ecol. Prog. Ser. 137 (1996) 283-291.

[9] P. M. Visser, J. J. Poos, B. B. Scheper, P. Boelen, F. C. van Duyl, Diurnal variations in depth profiles of UV-induced DNA damage and inhibition of bacterioplankton production in tropical coastal waters, Mar. Ecol. Prog. Ser. 228 (2002) 25-33. 
[10] B. Asquith, C. Debacq, D. C. Macallan, L. Willems, C. R. M. Bangham, Lymphocyte kinetics: the interpretation of labelling data, Trends Immunol. 23 (2002) 596-601.

[11] R. van Furth, T. L. van Zwet, Immunocytochemical Detection of 5-Bromo-2-Deoxyuridine Incorporation in Individual Cells, J. Immunol. Methods 108 (1988) 45-51.

[12] P. Aas, M. M. Lyons, R. Pledger, D. L. Mitchell, W. H. Jeffrey, Inhibition of bacterial activities by solar radiation in nearshore waters and the Gulf of Mexico, Aquat. Microb. Ecol. 11 (1996) 229-238.

[13] F. Joux, W. H. Jeffrey, P. Lebaron, D. L. Mitchell, Marine bacterial isolates display diverse responses to UV-B radiation, Appl. Environ. Microbiol. 65 (1999) 3820-3827.

[14] H. Agogué, F. Joux, I. Obernosterer, P. Lebaron, Resistance of marine bacterioneuston to solar radiation, Appl. Environ. Microbiol. 71 (2005) 5282-5289.

[15] J. M. Arrieta, M. G. Weinbauer, G. J. Herndl, Interspecific variability in sensitivity to UV radiation and subsequent recovery in selected isolates of marine bacteria, Appl. Environ. Microbiol. 66 (2000) 1468-1473.

[16] R. I. Amann, W. Ludwig, K. H. Schleifer, Phylogenetic identification and in situ detection of individual microbial cells without cultivation, Microbiol. Rev. 59 (1995) 143-169.

[17] G. Muyzer, E. C. de Waal, A. G. Uitterlinden, Profiling of complex microbial populations by denaturing gradient gel electrophoresis analysis of polymerase chain reaction-amplified genes coding for 16S rRNA, Appl. Environ. Microbiol. 59 (1993) 695-700.

[18] G. Muyzer, K. Smalla, Application of denaturing gradient gel electrophoresis (DGGE) and temperature gradient gel electrophoresis (TGGE) in microbial ecology, Anton. Leeuw. 73 (1998) 127-141.

[19] C. Winter, M. M. Moeseneder, G. J. Herndl, Impact of UV radiation on bacterioplankton community composition, Appl. Environ. Microbiol. 67 (2001) 665-672. 
[20] L. Alonso-Sáez, J. M. Gasol, T. Lefort, J. Hofer, R. Sommaruga, Effect of natural sunlight on bacterial activity and differential sensitivity of natural bacterioplankton groups in northwestern Mediterranean coastal waters, Appl. Environ. Microbiol. 72 (2006) 5806-5813.

[21] A. G. J. Buma, E. J. van Hannen, L. Roza, M. J. W. Veldhuis, W. W. C. Gieskes, Monitoring ultraviolet-B-induced DNA-damage in individual diatom cells by immunofluorescent thymine dimer detection, J. Phycol. 31 (1995) 314-321.

[22] R. P. Sinha, D. P. Häder, UV-induced DNA damage and repair: a review, Photoch. Photobil. Sci. 1 (2002) 225-236.

[23] D. G. Bard, B. B. Ward, A species-specific bacterial productivity method using immunomagnetic separation and radiotracer experiments, J. Microbiol. Meth. 28 (1997) 207-219.

[24] J. Borneman, Culture-independent identification of microorganisms that respond to specified stimuli, Appl. Environ. Microbiol. 65 (1999) 3398-3400.

[25] E. Urbach, K. L. Vergin, S. J. Giovannoni, Immunochemical detection and isolation of DNA from metabolically active bacteria, Appl. Environ. Microbiol. 65 (1999) 1207-1213.

[26] K. Hamasaki, Comparison of bromodeoxyuridine immunoassay with tritiated thymidine radioassay for measuring bacterial productivity in oceanic waters, J. Oceanogr. 62 (2006) 793-799.

[27] C. E. Nelson, C. A. Carlson, A nonradioactive assay of bacterial productivity optimized for oligotrophic pelagic environments, Limnol. Oceanogr-Meth. 3 (2005) 211-220.

[28] A. Pernthaler, J. Pernthaler, Diurnal variation of cell proliferation in three bacterial taxa from coastal North Sea waters, Appl. Environ. Microbiol. 71 (2005) 4638-4644.

[29] A. Pernthaler, J. Pernthaler, M. Schattenhofer, R. Amann, Identification of DNA-synthesizing bacterial cells in coastal North Sea plankton, Appl. Environ. Microbiol. 68 (2002) 5728-5736.

[30] G. F. Steward, F. Azam, Bromodeoxyuridine as an alternative to H-3-thymidine 
for measuring bacterial productivity in aquatic samples, Aquat. Microb. Ecol. 19 (1999) 57-66.

[31] F. Warnecke, R. Sommaruga, R. Sekar, J. S. Hofer, J. Pernthaler, Abundances, identity, and growth state of actinobacteria in mountain lakes of different UV transparency, Appl. Environ. Microbiol. 71 (2005) 5551-5559.

[32] K. Hamasaki, R. A. Long, F. Azam, Individual cell growth rates of marine bacteria, measured by bromodeoxyuridine incorporation, Aquat. Microb. Ecol. 35 (2004) 217-227.

[33] K. Hamasaki, A. Taniguchi, Y. Tada, R. A. Long, F. Azam, Actively growing bacteria in the Inland Sea of Japan, identified by combined bromodeoxyuridine immunocapture and denaturing gradient gel electrophoresis, Appl. Environ. Microbiol. 73 (2007) 2787-2798.

[34] A. Taniguchi, K. Hamasaki, Community structures of actively growing bacteria shift along a north-south transect in the western North Pacific, Environ. Microbiol. 10 (2008) 1007-1017.

[35] H. Kawai, Oceanography in the Oyashio and Kuroshio. in: J. Msuzawa (Ed.), Ocean physics II, TOKAI UNIVERSITY PRESS, Tokyo, (1972), pp. 146-147.

[36] H. Kawai, Statistical estimation of isotherms indicative of Kuroshio axis, Deep-Sea Res. 16 (1969) 109-115.

[37] T. Katano, M. Fukui, Y. Watanabe, Identification of cultured and uncultured picocyanobacteria from a mesotrophic freshwater lake based on the partial sequences of 16SrDNA, Limnology 2 (2001) 213-218.

[38] G. Muyzer, DGGE/TGGE a method for identifying genes from natural ecosystems, Curr. Opin. Microbiol. 2 (1999) 317-322.

[39] H. Schäfer, G. Muyzer, Denaturing gradient gel electrophoresis in marine microbial ecology. in: J. H. Paul (Ed.), Marine Microbiology, Academic press, San Diego, (2001), pp. 425-468.

[40] B. L. Maidak, J. R. Cole, C. T. Parker, G. M. Garrity, N. Larsen, B. Li, T. G. Lilburn, M. J. McCaughey, G. J. Olsen, R. Overbeek, S. Pramanik, T. M. Schmidt, J. M. Tiedje, C. R. Woese, A new version of the RDP (Ribosomal Database Project), Nucleic Acids Res. 27 (1999) 171-173. 
[41] S. F. Altschul, T. L. Madden, A. A. Schäffer, J. H. Zhang, Z. Zhang, W. Miller, D. J. Lipman, Gapped BLAST and PSI-BLAST: a new generation of protein database search programs, Nucleic Acids Res. 25 (1997) 3389-3402.

[42] S. Kumar, K. Tamura, M. Nei, MEGA3: Integrated software for molecular evolutionary genetics analysis and sequence alignment, Brief. Bioinform. 5 (2004) 150-163.

[43] T. H. Jukes, C. R. Cantor, Mammalian protein metabolism. in: H. N. Munro (Ed.), Evolution of protein molecules, Academic Prss, New York, (1969), pp. 21-132.

[44] J. M. Gasol, a. M. Simons, J. Kalff, Patterns in the top-down versus bottom-up regulation of heterotrophic nanoflagellates in temperate lakes, J. Plankton Res. 17 (1995) 1879-1903.

[45] E. B. Sherr, B. F. Sherr, Significance of predation by protists in aquatic microbial food webs, Anton. Leeuw. 81 (2002) 293-308.

[46] D. Hanelt, Capability of dynamic photoinhibition in Arctic macroalgae is related to their depth distribution, Mar. Biol. 131 (1998) 361-369.

[47] G. J. Herndl, Role of ultraviolet radiation on bacterioplankton activity. in: D. P. Hader (Ed.), The effects of ozone depletion on aquatic ecosystems, Academic Press, San Diego, (1997), pp. 143-150.

[48] V. F. Zenoff, F. Siñeriz, M. E. Farías, Diverse responses to UV-B radiation and repair mechanisms of bacteria isolated from high-altitude aquatic environments, Appl. Environ. Microb. 72 (2006) 7857-7863.

[49] E. Kaiser, G. J. Herndl, Rapid recovery of marine bacterioplankton activity after inhibition by UV radiation in coastal waters, Appl. Environ. Microbiol. 63 (1997) 4026-4031.

[50] D. J. Kieber, J. Mcdaniel, K. Mopper, Photochemical source of biological substrates in sea water - implications for carbon cycling, Nature 341 (1989) $637-639$

[51] D. J. Kieber, K. Mopper, Photochemical formation of glyoxylic and pyruvic acids in seawater, Mar. Chem. 21 (1987) 135-149. 
[52] M. Kulovaara, Light-induced degradation of aquatic humic substances by simulated sunlight, Int. J. Environ. An. Ch. 62 (1996) 85-95.

[53] K. Mopper, W. L. Stahovec, Sources and sinks of low molecular weight organic carbonyl compounds in seawater, Mar. Chem. 19 (1986) 305-321.

[54] K. Mopper, X. L. Zhou, R. J. Kieber, D. J. Kieber, R. J. Sikorski, R. D. Jones, Photochemical degradation of dissolved organic carbon and its impact on the oceanic carbon cycle, Nature 353 (1991) 60-62.

[55] M. J. Lindell, W. Granéli, L. J. Tranvik, Enhanced bacterial growth in response to photochemical transformation of dissolved organic matter, Limnol. Oceanogr. 40 (1995) 195-199.

[56] I. Obernosterer, B. Reitner, G. J. Herndl, Contrasting effects of solar radiation on dissolved organic matter and its bioavailability to marine bacterioplankton, Limnol. Oceanogr. 44 (1999) 1645-1654.

[57] J. M. González, R. Simó, R. Massana, J. S. Covert, E. O. Casamayor, C. Pedrós-Alió, M. A. Moran, Bacterial community structure associated with a dimethylsulfoniopropionate-producing North Atlantic algal bloom, Appl. Environ. Microbiol. 66 (2000) 4237-4246.

[58] M. T. Suzuki, C. M. Preston, F. P. Chavez, E. F. DeLong, Quantitative mapping of bacterioplankton populations in seawater: field tests across an upwelling plume in Monterey Bay, Aquat. Microb. Ecol. 24 (2001) 117-127.

[59] B. A. S. Van Mooy, A. H. Devol, R. G. Keil, Relationship between bacterial community structure, light, and carbon cycling in the eastern subarctic North Pacific, Limnol. Oceanogr. 49 (2004) 1056-1062.

[60] E. B. M. Denner, D. Vybiral, M. Koblížek, P. Kämpfer, H. J. Busse, B. Velimirov, Erythrobacter citreus sp nov., a yellow-pigmented bacterium that lacks bacteriochlorophyll a, isolated from the western Mediterranean Sea, Int. J. Syst. Evol. Micr. 52 (2002) 1655-1661. 


\section{Figure legends}

Fig. 1. Daily variation of solar UV radiation $\left(\mathrm{W} \mathrm{m}^{-2}\right)$ on each sampling day. Arrows represent sampling time.

Fig. 2. DGGE image of $16 \mathrm{~S}$ rRNA genes amplified from total (To), BrdU-incorporating (Br), and thymine-dimer-accumulating (TD) community obtained at each sampling station. Triangles represent excised and sequenced bands. Lane M was used as a marker lane.

Fig. 3. Relationship between total, BrdU-incorporating, and thymine-dimeraccumulating communities from each sampling station. The dissimilarity tree was constructed from the binary matrix translated from a DGGE image (Fig. 2).

Fig. 4. A neighbor-joining tree of partial 16S rDNA sequences obtained from DGGE bands (see Fig. 2). The scale bar represents 0.05 substitutions per nucleotide position. 


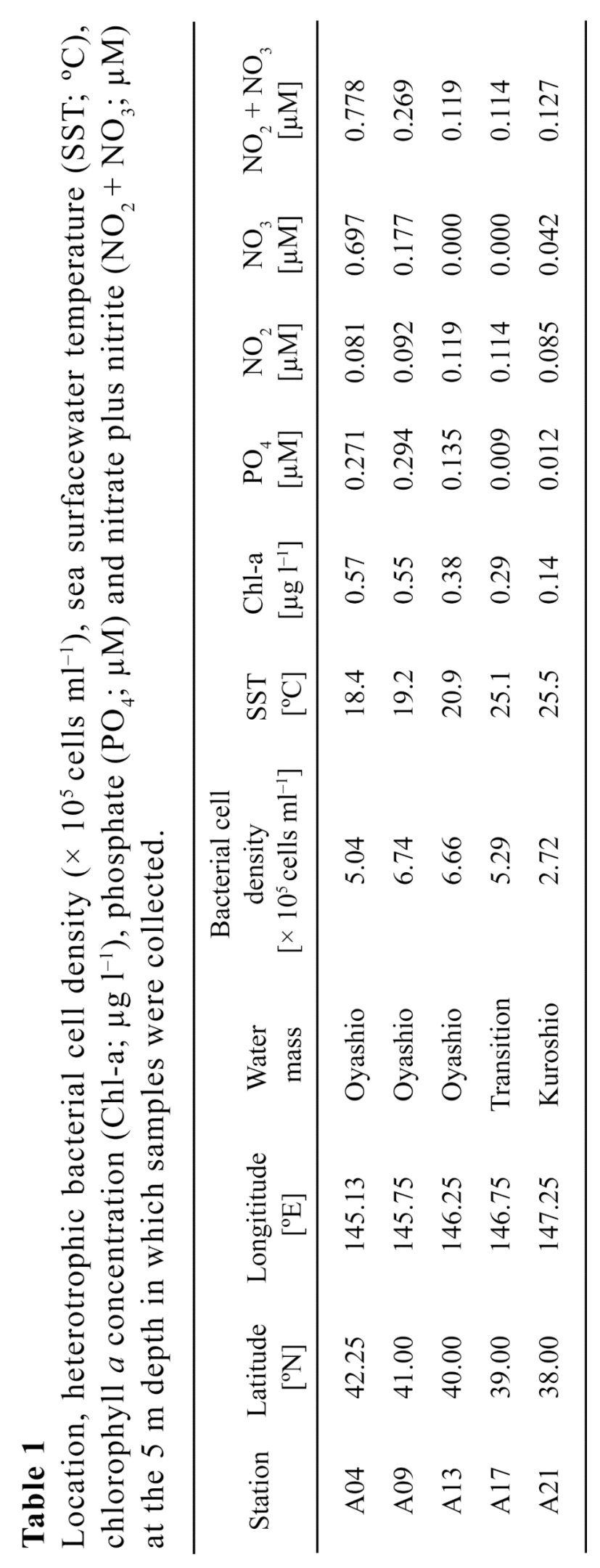




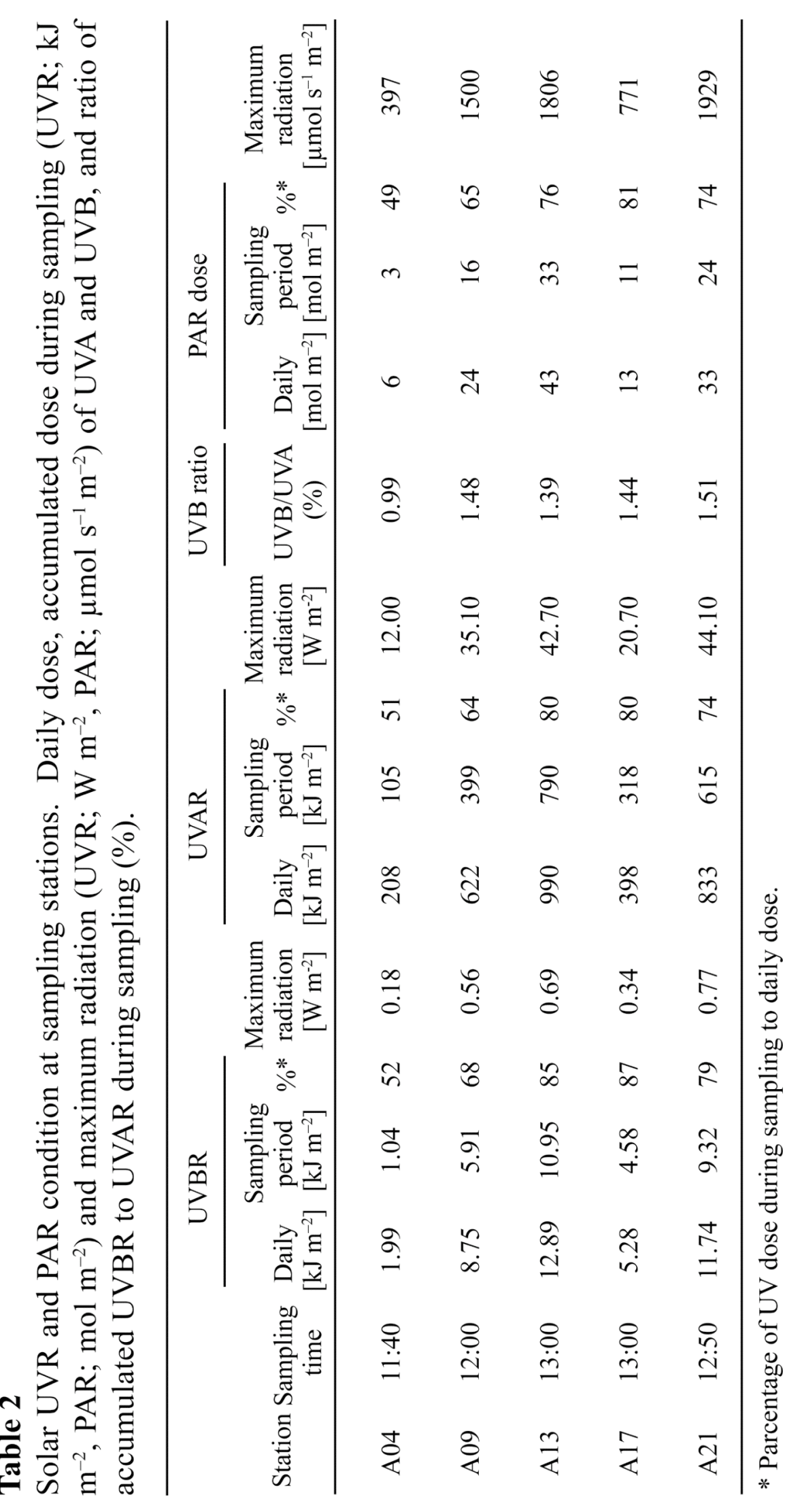




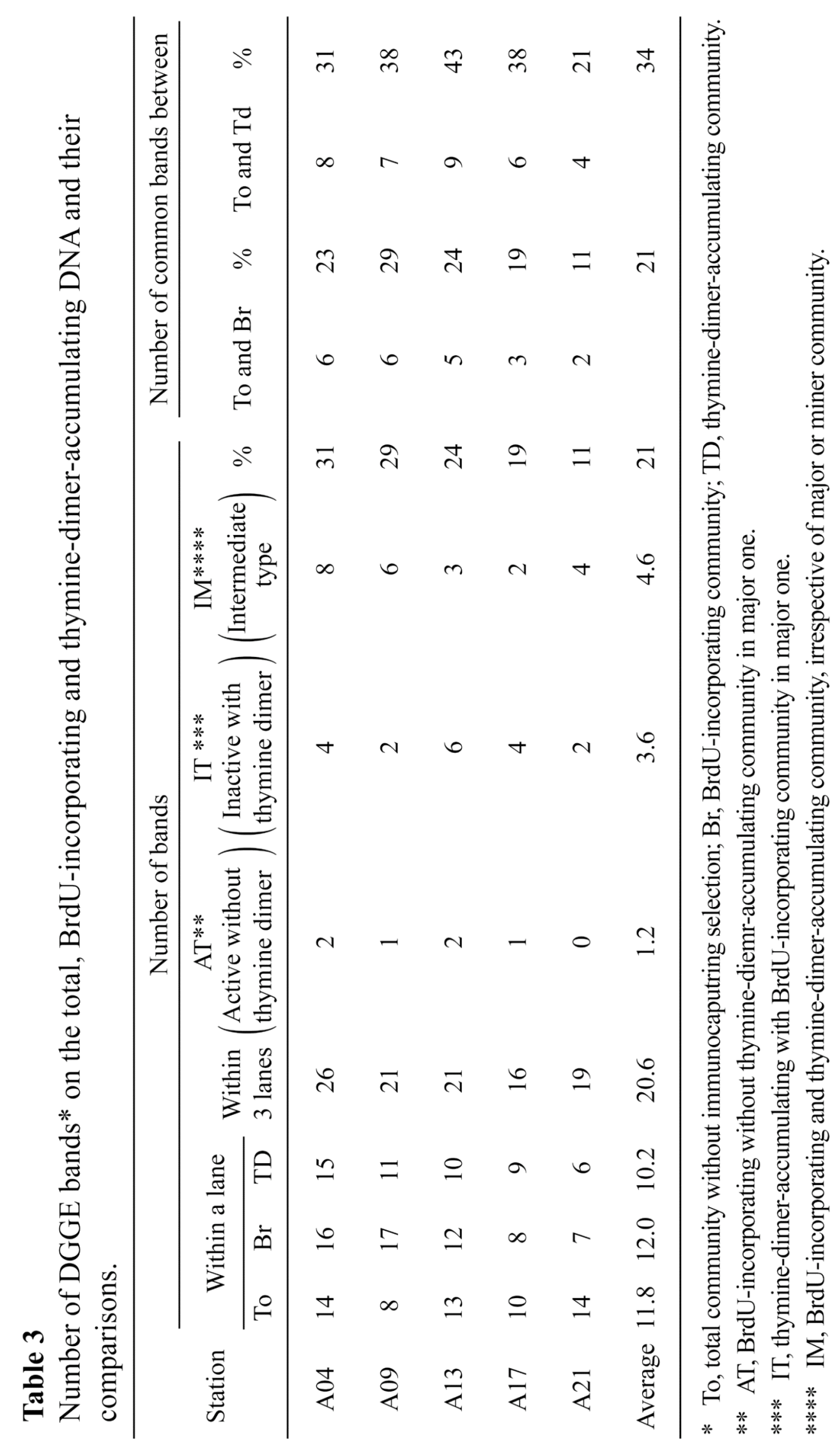




\section{Table 4}

Affiliation of excited DGGE band sequences with other seauences depositted in DDBJ.

\begin{tabular}{|c|c|c|c|c|c|}
\hline $\begin{array}{c}\text { Sequence } \\
\text { name }\end{array}$ & $\begin{array}{l}\text { DGGE } \\
\text { band } \\
\text { position }\end{array}$ & Group* & $\begin{array}{l}\text { Closest relative's form name } \\
\text { (Accession No.) }\end{array}$ & $\begin{array}{l}\text { Sequence } \\
\text { length }\end{array}$ & $\begin{array}{l}\text { Similarity } \\
(\%)\end{array}$ \\
\hline \multicolumn{6}{|c|}{ Active without thymine dimer (AT) } \\
\hline AT_1 & 09 & $\alpha$, Sphi & $\begin{array}{l}\text { Erythrobacter sp. MED365 } \\
\text { (EU253576) }\end{array}$ & 508 & 97.7 \\
\hline AT_2 & 02 & $\mathrm{Bac}$ & $\begin{array}{l}\text { clone SPOTSAPR01_5m159 } \\
\text { (DQ009089) }\end{array}$ & 541 & 100.0 \\
\hline AT_3 & 10 & $\gamma$ & clone ALN_al06 (AB364989) & 545 & 96.1 \\
\hline \multicolumn{6}{|c|}{ Inactive with thymine dimer (IT) } \\
\hline IT_1 & 07 & $\gamma$, Pseu & $\begin{array}{l}\text { Pseudoalteromonas sp. 36D8 } \\
\text { (EF033416) }\end{array}$ & 545 & 99.5 \\
\hline IT_2 & 11 & Cya & clone 20162U93 (EU237472) & 527 & 100.0 \\
\hline IT_3 & 12 & Суа & $\begin{array}{l}\text { Prochlorococcus marinus } \\
\text { TAK9803-2 (AF311220) }\end{array}$ & 526 & 99.8 \\
\hline IT_4 & 01 & $\alpha$, Cand & clone 20162U66 (EU237450) & 506 & 87.4 \\
\hline IT_5 & 08 & $\alpha$, Rose & $\begin{array}{l}\text { Uncultured Roseobacter sp. } \\
\text { clone EF100- 65C12 (AY627371) }\end{array}$ & 523 & 100.0 \\
\hline IT_6 & 03 & plastid & $\begin{array}{l}\text { DGGE gel band LUR7 } \\
\text { (AY960282) }\end{array}$ & 528 & 95.8 \\
\hline \multicolumn{6}{|c|}{ Intermediate type (IM) } \\
\hline IM_1 & 15 & Actino & $\begin{array}{l}\text { Propionibacterium acnes } \\
\text { isolate Asn14 (DQ672261) }\end{array}$ & 531 & 100.0 \\
\hline IM_2 & 06 & $\alpha$, Rose & clone S25_1451 (EF575107) & 520 & 100.0 \\
\hline IM_3 & 04 & $\mathrm{Bac}$ & clone OCS182 (AF001660) & 528 & 100.0 \\
\hline IM_4 & 13 & Суа & $\begin{array}{l}\text { Synechococcus sp. WH } 8109 \\
\text { (AY172836) }\end{array}$ & 527 & 100.0 \\
\hline \multicolumn{6}{|c|}{ Not characterized } \\
\hline NO_1 & 05 & $\alpha$, Rose & clone CZII_q2 (AB355769) & 523 & 100.0 \\
\hline NO_2 & 14 & $\mathrm{Bac}$ & $\begin{array}{l}\text { Uncultured Oceanospirillales } \\
\text { clone ESP200-K15-10 (DQ810547 }\end{array}$ & 7) 526 & 89.0 \\
\hline
\end{tabular}

* $\alpha, \gamma$, Bac, Cya, Cand and Actino indicate Alpha-, Gammaproteobacteria, unknown group of bacteria, Cyanobacteria, Candidus and Actinobacteria, respectively; Sphi, Sphingomonas spp.; Pseu, Pseudoalteromonas spp.; Rose, Roseobacter spp. 


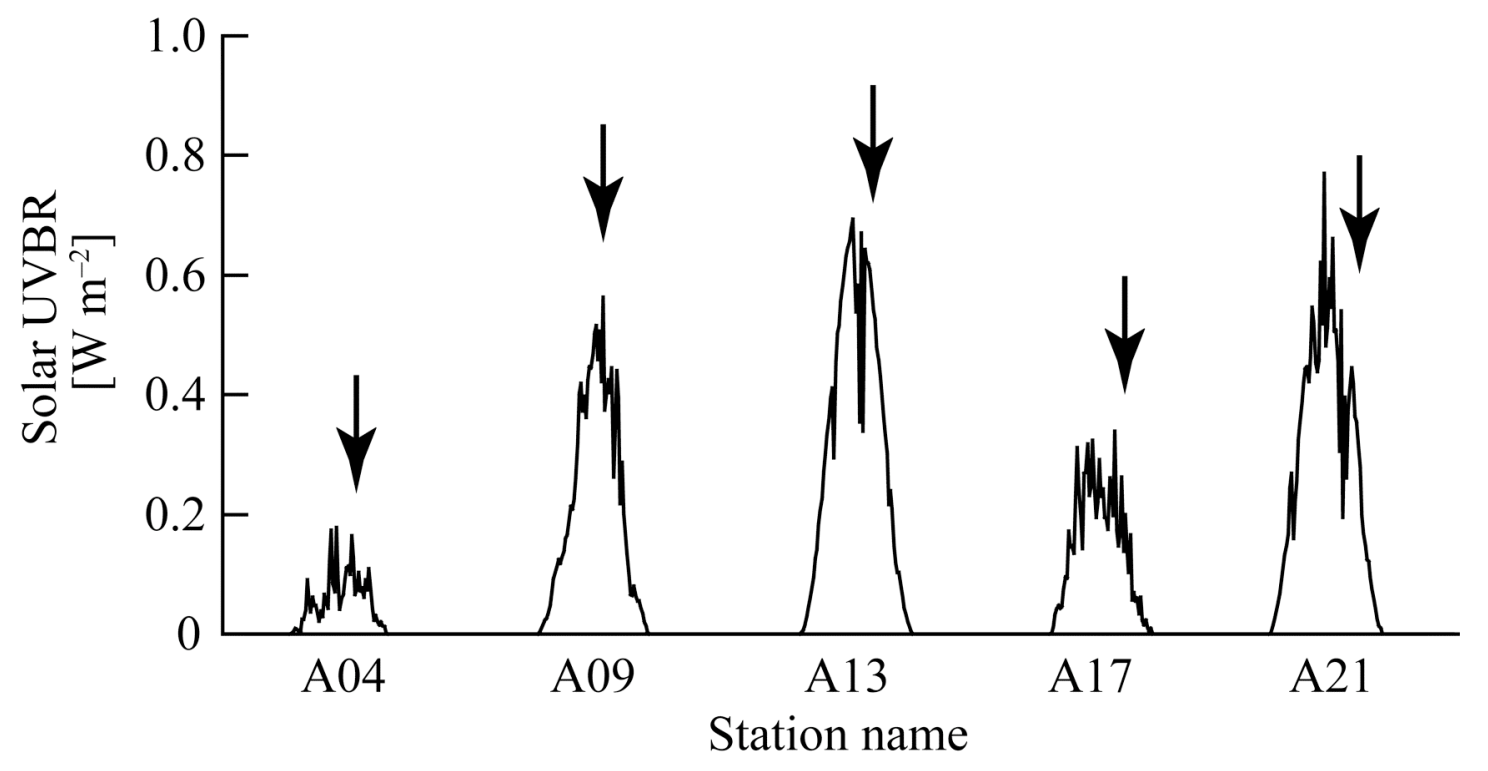

Fig. 1 Kataoka et al. 


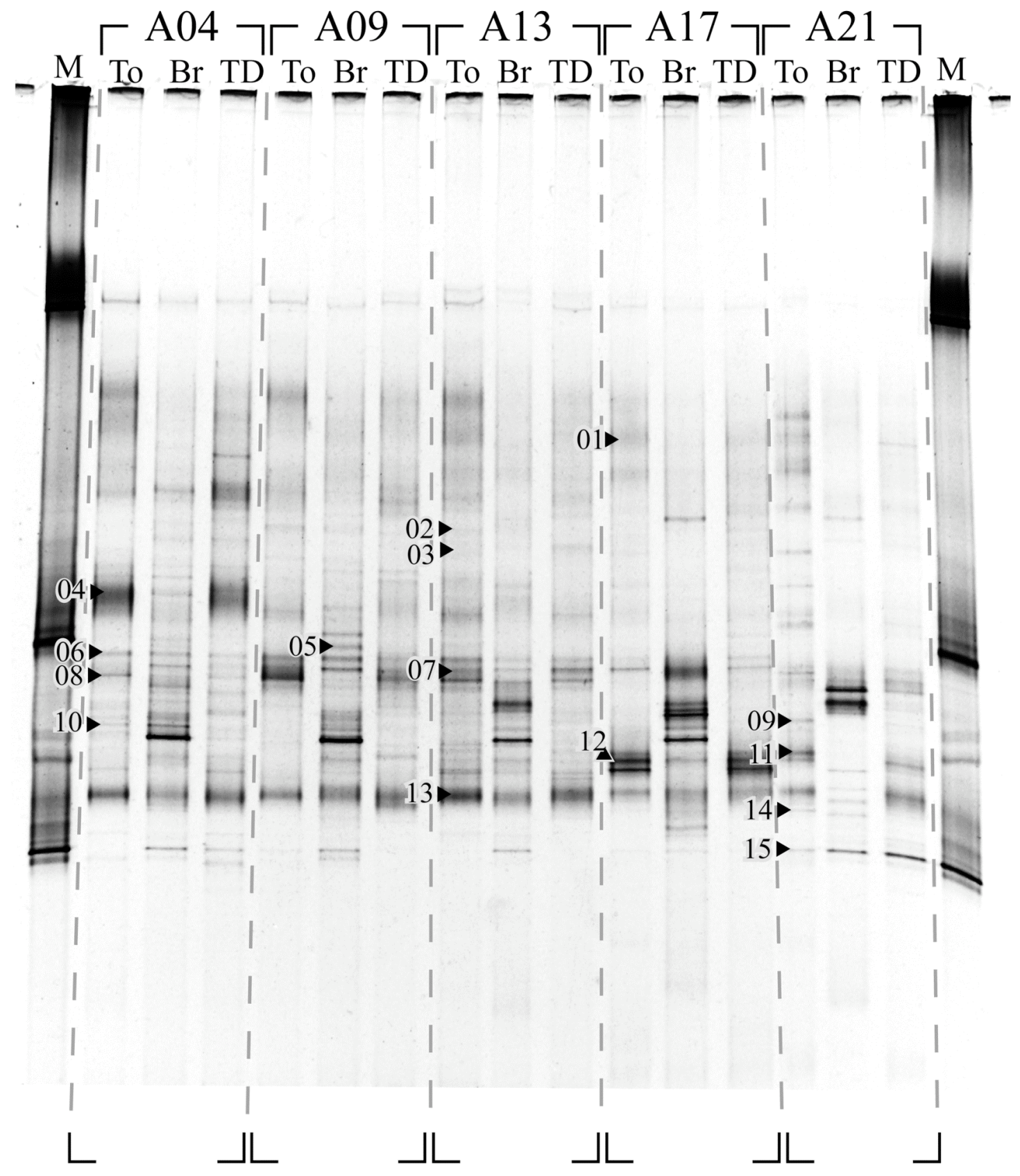

Fig. 2 Kataoka et al. 


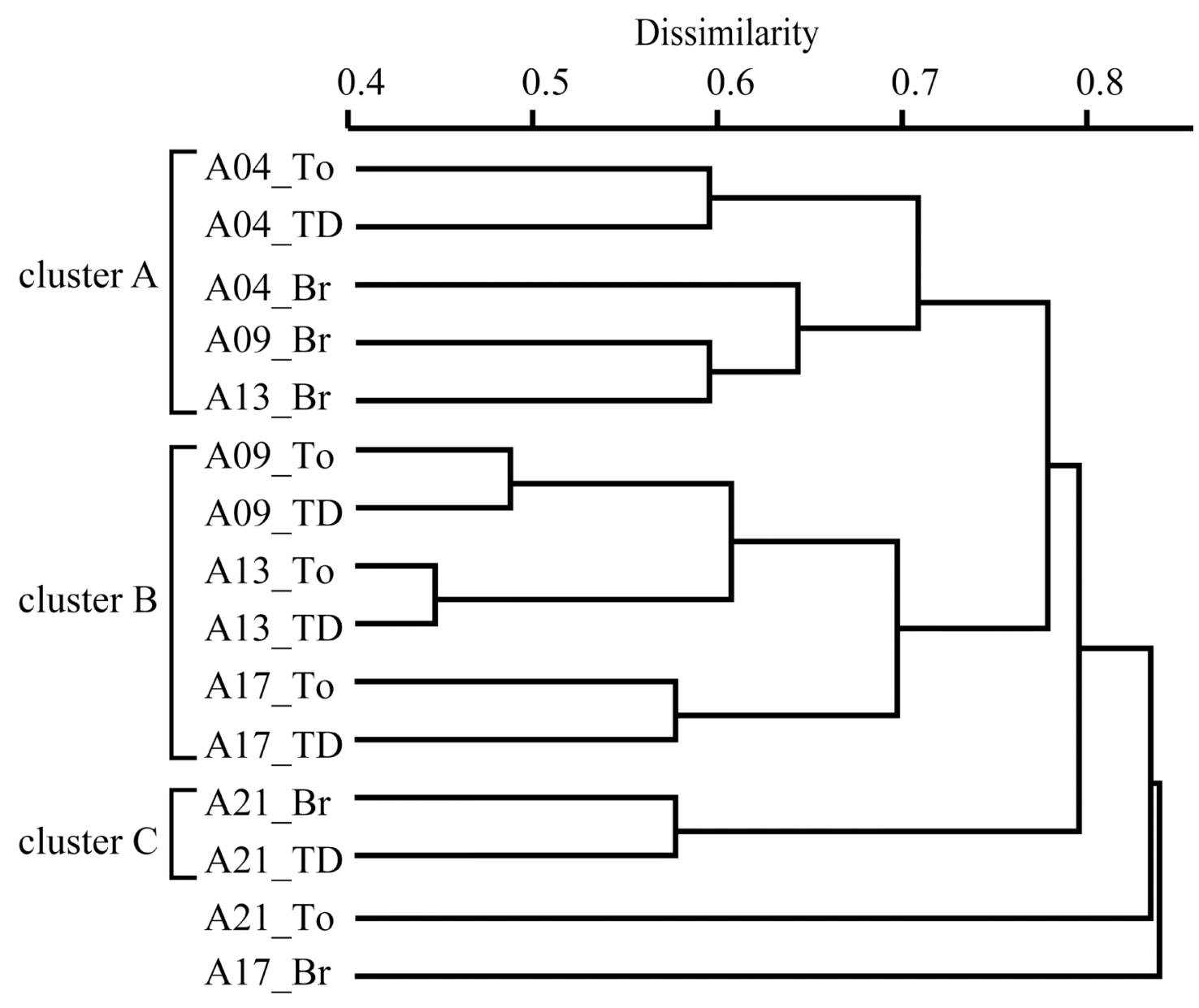

Fig. 3 Kataoka et al. 


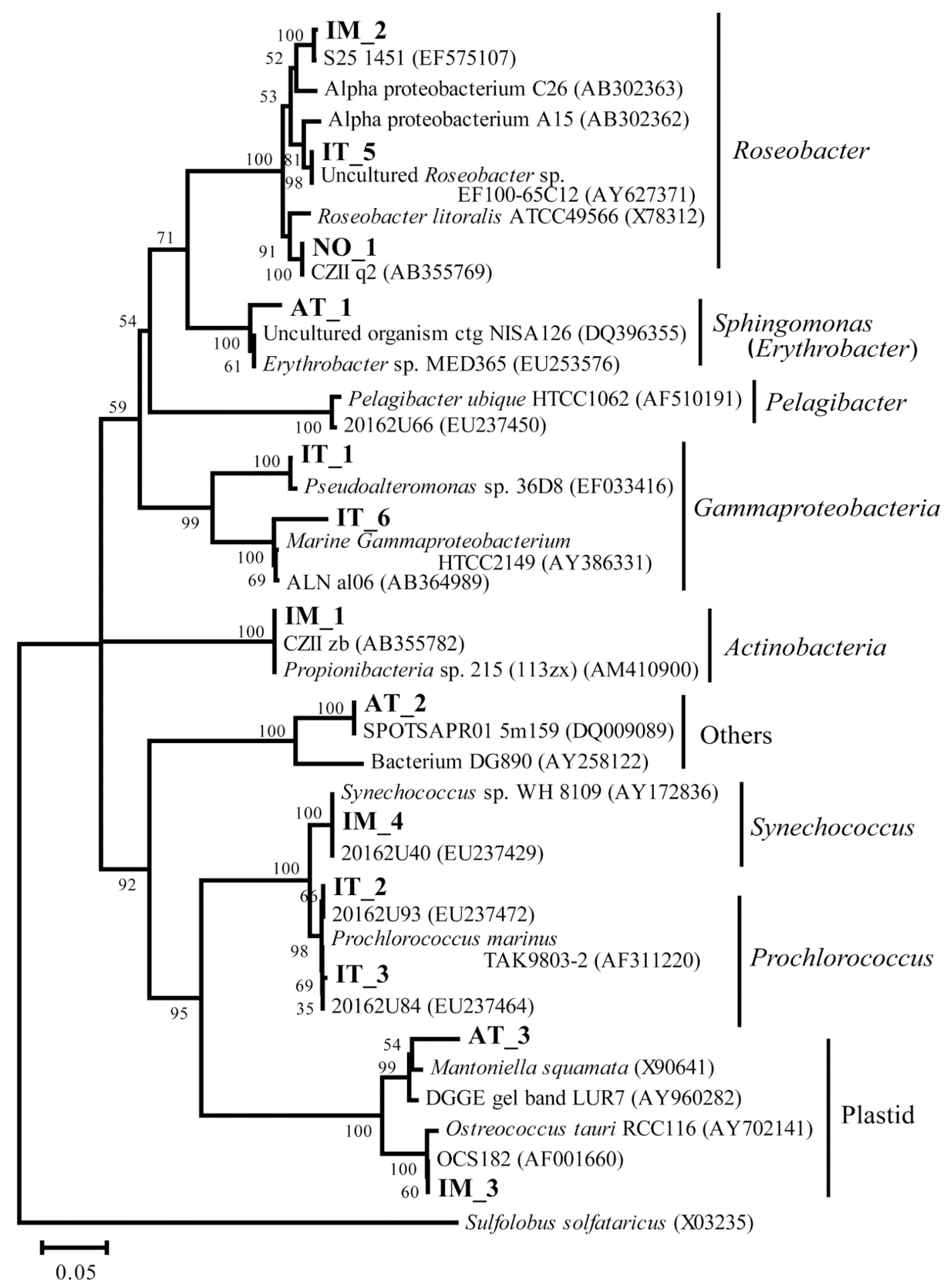

Fig. 4 Kataoka et al. 